\title{
Synthesis and characterization of binary complexes of furcellaran with gelatin and bovine serum albumin
}

\author{
Ewelina Jamróz $^{1), *)}$, Anna Konieczna-Molenda ${ }^{1)}$, Andrzej Para ${ }^{1)}$ \\ DOI: dx.doi.org/10.14314/polimery.2018.6.2
}

\begin{abstract}
Furcellaran (FUR) complexes with albumin (BSA) and gelatin (GEL) were investigated. The

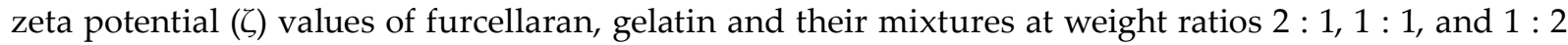
$(\mathrm{w} / \mathrm{w})$ were measured over a $\mathrm{pH}$ range 2.0-10.0. FUR/GEL and FUR/BSA complexes were prepared by the electrolysis of aqueous solutions of both components taken in the $1: 1(\mathrm{w} / \mathrm{w})$ ratio. The results of the elemental analysis, FT-IR spectroscopy and thermal analysis confirmed the formation of the complexes. The investigated complexes differed in their susceptibility to enzymatic hydrolysis and solubility. At room temperature, the solubility of FUR/GEL and FUR/BSA complexes was $0.055 \pm 0.021 \mathrm{~g} / 100 \mathrm{~cm}^{3} \mathrm{H}_{2} \mathrm{O}$ and $0.031 \pm 0.020 \mathrm{~g} / 100 \mathrm{~cm}^{3} \mathrm{H}_{2} \mathrm{O}$, respectively. Different structures of FUR/GEL and FUR/BSA complexes, determined by SEM studies, can explain differences in both solubility and hydrolytic susceptibility. Enzymatic studies showed that the furcellaran/gelatin and furcellaran/bovine serum albumin complexes are biodegradable. The complexes were not physical mixtures of the components.
\end{abstract}

Keywords: albumin, furcellaran, gelatin, polysaccharide-protein complexes.

\section{Otrzymywanie i charakterystyka binarnych kompleksów furcellaranu z żelatyną i albuminą surowicy bydlęcej}

Streszczenie: Badano kompleksy furcellaranu (FUR) z albuminą (BSA) oraz żelatyną (GEL). Wartości

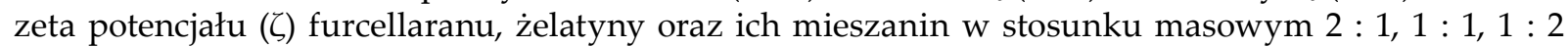
określono w zakresie pH 2,0-10,0. Kompleksy FUR/GEL oraz FUR/BSA otrzymano metodą elektrosyntezy przy stosunku masowym $1: 1$. Metodami analizy elementarnej (EA), spektroskopii w podczerwieni z transformacją Fouriera (FT-IR) oraz analizy termicznej (DSC, TGA) potwierdzono powstanie kompleksów FUR/GEL i FUR/BSA. Otrzymane kompleksy różniły się podatnością na hydrolizę enzymatyczną i rozpuszczalnością. $W$ temperaturze pokojowej rozpuszczalność kompleksów FUR/GEL i FUR/BSA wynosiła, odpowiednio, 0,055 $\pm 0,021 \mathrm{~g} / 100 \mathrm{~cm}^{3} \mathrm{H}_{2} \mathrm{O}$ i 0,031 $\pm 0,020 \mathrm{~g} / 100 \mathrm{~cm}^{3} \mathrm{H}_{2} \mathrm{O}$. Obserwowana na zdjęciach SEM odmienna struktura kompleksów może tłumaczyć różnice $\mathrm{w}$ ich rozpuszczalności oraz podatności na hydrolizę enzymatyczną. Analiza przebiegu hydrolizy wskazywała na biodegradowalność badanych kompleksów. Potwierdzono, że otrzymane kompleksy nie są fizycznymi mieszaninami składników.

Słowa kluczowe: albumina, furcellaran, żelatyna, kompleksy polisacharydowo-białkowe.

Combining biopolymers such as proteins and polysaccharides results in the formation of natural complexes see, for instance, review [1]. Factors determining the formation of the complexes are size (molecular weight) and type of biopolymers, that is, their chain conformations, flexibility, localization of reaction sites and charge density over their $\mathrm{pH}$, ionic strength and temperature dependent solubility, polysaccharide to protein ratio, and overall biopolymer concentration [2]. However, the anionic characteristics of polysaccharides combined with proteins are the most crucial

\footnotetext{
1) University of Agriculture, Institute of Chemistry, Balicka 122, 30-149 Cracow, Poland.

*) Author for correspondence:

e-mail: ewelina.jamroz@urk.edu.pl
}

factors. Thus, recent reports on the formation of such binary complexes involve anionic polysaccharides such as potato starch [3-5], phosphorylated starches [6, 7], carboxymethyl cellulose [8-10], carrageenans [11-13], furcellaran [14], various polysaccharide carboxylates such as pectins [15-18], hyaluronic acid [19, 20], xanthan gum [21, 22], chitosan [23] and other polysaccharide carboxylates [24, 25]. The formation of the complexes is based on bringing the blends of the components to an isoelectric point providing the complexation of the ionized components. Reaching the isoelectric point can involve either regular titration $[5-7,13,23]$ or electrosynthesis $[3,4,8-12,17,22]$. The complexation of natural anionic polysaccharides with proteins, provides potentially biodegradable either covalent or electrostatic, hydrophobic or non-polar complexes. For the formation of such complexes, 
polysaccharides sourced from plant materials such as distillery corn grain [26], corncobs [27], sawdust [28], and agricultural waste [29] can be utilized with soy protein to provide a biodegradable material with mechanical properties resembling styrene-butadiene synthetic polymers.

Polysaccharide-protein complexes formed in food systems play a role in improving the functional properties of foodstuffs. Such complexes can be used as meat and fat replacers, nanocapsules and edible coatings. Many polysaccharide-protein complexes have found applications in the food industry, medicine, pharmacy and cosmetics [30].

Furcellaran is a negatively charged polysaccharide extracted from red algae Furcellaria lumbricalis. It is composed of $(1 \rightarrow 3)-\beta$-D-galactopyranose and its 4 -sulfate modification, and $(1 \rightarrow 4)-\alpha$-D-galactopyranose [31]. For structural and functional properties, furcellaran can be related to $\kappa$-carrageenan. In the food industry, furcellaran is used as a thickener, stabilizer and emulsifier (E 407).

In the present paper, the electrochemical syntheses of anionic polysaccharide - furcellaran (FUR) - binary complexes with either bovine serum albumin (BSA) or gelatin (GEL) as the protein component are presented.

The electrochemical synthesis applied for the preparation of furcellaran/protein complexes appeared reproducible for the preparation of stoichiometric polysaccharide/protein complexes, which separated on the anode, being a suitable method for the preparation of a wide range of polysaccharide/protein complexes.

The complexes are environmentally benign as they enzymatically hydrolyze primarily into individual amino acids $[32,33]$ and monosaccharides [34, 35], and then into ammonia, carbon dioxide and water.

The objectives of the study were:

- to determine the zeta potential of FUR/GEL and FUR/BSA complexes [36] under different concentrations and $\mathrm{pH}$;

- to describe the process of electrosynthesis of FUR/ GEL and FUR/BSA binary complexes.

\section{EXPERIMENTAL PART}

\section{Materials}

- Furcellaran (FUR) was purchased from the Est-Agar Company (Karla Village, Estonia);

- Gelatin (GEL) was isolated from Canadian fish skin (Sigma-Aldrich, Poland, catalogue no. G7765);

- Bovine serum albumin (BSA), fraction V, lyophilized powder, $99 \%$ was purchased from Sigma-Aldrich, Poland;

- Trypsin from porcine pancreas, lyophilized powder, BioReagent, suitable for cell culture, 1000-2000 BAEE units/mg solid (Sigma-Aldrich, Poznan, Poland), [ 270 BAEE units correspond to 1 international unit $(\mathrm{U})$ at $\left.25^{\circ} \mathrm{C}\right]$;

- Glucoamylase OPTIDEX ${ }^{\circledR}$ L-400 401-04122-001 (Genencor International, USA) isolated from fungus with activity of $365 \mathrm{U} / \mathrm{g}$ at $\mathrm{pH} 4.0-5.5$ and $35-40^{\circ} \mathrm{C}$.
All materials were used without further purification. The distilled water used in all experiments was produced with the three-stage Millipore Direct-Q 3UV purification system. The experiments were performed at room temperature $\left[22{ }^{\circ} \mathrm{C}(295 \mathrm{~K})\right]$.

\section{Complex formation}

$15 \mathrm{~cm}^{2}$ platinum electrodes were placed in a beaker $\left(200 \mathrm{~cm}^{3}\right)$ with a $2.5 \mathrm{~cm}$ distance. The beaker was filled with aqueous solutions of FUR $(1 \%, w / w)$ and protein $(1 \%, w / w)$. Electrodes were connected to the feeder (DC POWER A 605D, PowerLab). The electrosynthesis was conducted at room temperature and $20 \mathrm{~V}$ with an initial current intensity of $0.18 \pm 0.1 \mathrm{~A}$.

The complex covered the anode and it was removed after each $5 \mathrm{~min}$ period, washed twice on the filter with an acetone : water $(2: 1)$ solution $\left(20 \mathrm{~cm}^{3}\right)$, and then with acetone $\left(20 \mathrm{~cm}^{3}\right)$ and left to dry at room temperature. The complex formation was conducted in triplicate.

\section{Enzymatic degradation}

FUR/GEL and FUR/BSA complexes, as well as the individual components of those complexes, were separately digested with glucoamylase and with trypsin. Both the protein and polysaccharide components of the complexes were subjected to enzymatic digestion. The polysaccharide component of the complex was hydrolyzed by glucoamylase. Glucoamylase $\left(0.25 \mathrm{~cm}^{3}\right.$ of commercial product) was introduced to the aqueous suspension of the complex $\left(0.1 \mathrm{~g} / 200 \mathrm{~cm}^{3} \mathrm{H}_{2} \mathrm{O}\right)$ and the flask was placed in a shaker at $37.7^{\circ} \mathrm{C}$. The reaction course was monitored spectrophotometrically by controlling the level of the reducing sugar by the Miller method utilizing 3,5-dinitrosalicylic acid [37].

The reaction course of the protein digestion by trypsin was monitored by titration according to Sörensen (the formol method) [38]. The trypsin solution was prepared $\left(0.1 \mathrm{~g}\right.$ in $\left.10 \mathrm{~cm}^{3} \mathrm{H}_{2} \mathrm{O}\right)$ and added to the complex $\left(0.1 \mathrm{~g} / 190 \mathrm{~cm}^{3} \mathrm{H}_{2} \mathrm{O}\right)$. The mixture was incubated in a water bath at $37.7{ }^{\circ} \mathrm{C}$. Immediately after mixing, $2 \mathrm{~cm}^{3}$ of the mixture was collected and transferred to a measuring flask $\left(50 \mathrm{~cm}^{3}\right)$ containing $4 \mathrm{~cm}^{3}$ of formalin (control test). The control test was titrated with $0.02 \mathrm{M} \mathrm{NaOH}$ solution against phenolphthalein. Samples collected at $10 \mathrm{~min}$ intervals were analyzed identically. The amount of consumed titrant was recalculated for the amount [ $\mu \mathrm{mol}]$ of protons of carboxylic groups $\left(1 \mathrm{~cm}^{3}\right.$ of $0.02 \mathrm{M}$ aq. $\mathrm{NaOH}$ solution is equivalent to $20 \mu$ moles of $\mathrm{COOH}$ groups).

\section{Methods of testing}

\section{Zeta potential measurements}

A Zetasizer Nano ZS Malvern (Worchestershire, UK) was used to determine the zeta potentials for FUR and GEL solutions and FUR+GEL mixtures in $0.005 \mathrm{M} \mathrm{NaCl}$. 
The initial concentration of FUR and GEL was 1000 ppm. Zeta potential analyses were conducted in triplicate.

\section{Solubility}

The complex was dried for $5 \mathrm{~h}$ at $100{ }^{\circ} \mathrm{C}$. Then, $0.2 \pm 0.0001 \mathrm{~g}$ sample was placed in distilled water $\left(100 \mathrm{~cm}^{3}\right)$. The suspension was left at room temperature without stirring. After $24 \mathrm{~h}$, the residues were filtered and dried at $100{ }^{\circ} \mathrm{C}$ for $2 \mathrm{~h}$. Additionally, solubility tests in DMSO and $7 \mathrm{M}$ aqueous urea at room temperature were conducted. The precipitate was weighed, the solubility of the product was determined. The estimations were triplicated.

\section{Elemental analysis}

The elemental analysis for $\mathrm{C}, \mathrm{H}$ and $\mathrm{N}$ was performed with an EURO EA 3000 Elemental Analyser (EuroVector, Italy).

\section{FT-IR spectra}

FT-IR spectra of complexes and of all components were examined in the range of $4000-500 \mathrm{~cm}^{-1}$ in $\mathrm{KBr}$ discs (3 mg in $300 \mathrm{mg} \mathrm{KBr}$ ) using a Mattson 3000 FTIR spectrophotometer (Pye-Unicam, Cambridge, UK).

\section{Differential scanning calorimetry (DSC)}

DSC experiments were performed with a Mettler-Toledo 821e (Columbus, Ohio, USA) calorimeter equipped with an Haake intracooler (Apeldoorn, Nederland) under a constant flow of argon $\left(80 \mathrm{~cm}^{3} / \mathrm{min}\right)$ within the temperature range of $25-500{ }^{\circ} \mathrm{C}$ at the heating rate of $10{ }^{\circ} \mathrm{C} / \mathrm{min}$. Samples $(2-3 \mathrm{mg})$ were placed in $40 \mathrm{~mm}^{3}$ hermetically closed aluminum pans. DSC analyses were conducted in triplicate.

\section{Thermogravimetric analysis}

Thermogravimetric analysis was performed using a thermogravimetric analyzer TGA701 (LECO Corporation, St. Joseph, MI, USA). Samples ( $0.2 \mathrm{~g})$ were placed in ceramic crucibles and heated from $25^{\circ} \mathrm{C}$ to $650{ }^{\circ} \mathrm{C}$ at $2{ }^{\circ} \mathrm{C} / \mathrm{min}$ under nitrogen $\left(3.5 \mathrm{dm}^{3} / \mathrm{min}\right)$. Weight loss (TG) and first derivative of weight loss (DTG) in time dependence on temperature were recorded.

T a b l e 1. The physicochemical properties of furcellaran, gelatin and bovine serum albumin

\begin{tabular}{c|c|c}
\hline Sample & $\begin{array}{c}\text { Molecular weight } \\
\mathrm{kDa}\end{array}$ & $\begin{array}{c}\text { Isoelectric } \\
\text { point }\end{array}$ \\
\hline $\begin{array}{c}\text { Bovine serum albumin } \\
\text { (BSA) }\end{array}$ & 67.4 & 4.8 \\
Gelatin (GEL) & 29.6 & $4.0-8.0$ \\
Furcellaran (FUR) & 255 & - \\
\hline
\end{tabular}

\section{Surface morphology}

The surface morphology of complexes was observed by the scanning electron microscope JEOL JSM-7500F (Japan).

\section{RESULTS AND DISCUSSION}

\section{Effect of the component ratio on the furcellaran/ protein complex}

The physicochemical properties of BSA, GEL and FUR are shown in Table 1.

Zeta potential manifests the presence of charged molecules in the system. The change of its value upon the formation of complexes can be a convenient indicator in studying the complexation. Thus, zeta potentials of the individual components and the FUR+GEL mixtures at varying polysaccharide : protein concentration ratio were investigated. The results are shown in Fig. 1.

The measurements of zeta potential of FUR+BSA mixtures were previously reported. The formation of FUR/ BSA complexes at varying ratios and $\mathrm{pH}$ were monitored by changes of zeta potential. The optimum conditions for FUR/BSA complex formation as a core of nanocapsules were determined [23].

GEL showed a net positive charge because, below the isoelectric point, proteins carry a net positive charge. When the $\mathrm{pH}$ decreased, an increase in the zeta potential values might contribute to the increasing number of positively charged amino groups, while the dissociation of the carboxyl groups was suppressed. Negative charges for FUR were observed in a wide range of $\mathrm{pH}$ from 2 to 10. As shown in Fig. 1, the net charge of FUR+GEL mixture in the $2: 1(\mathrm{w} / \mathrm{w})$ ratio remained negative, indicating

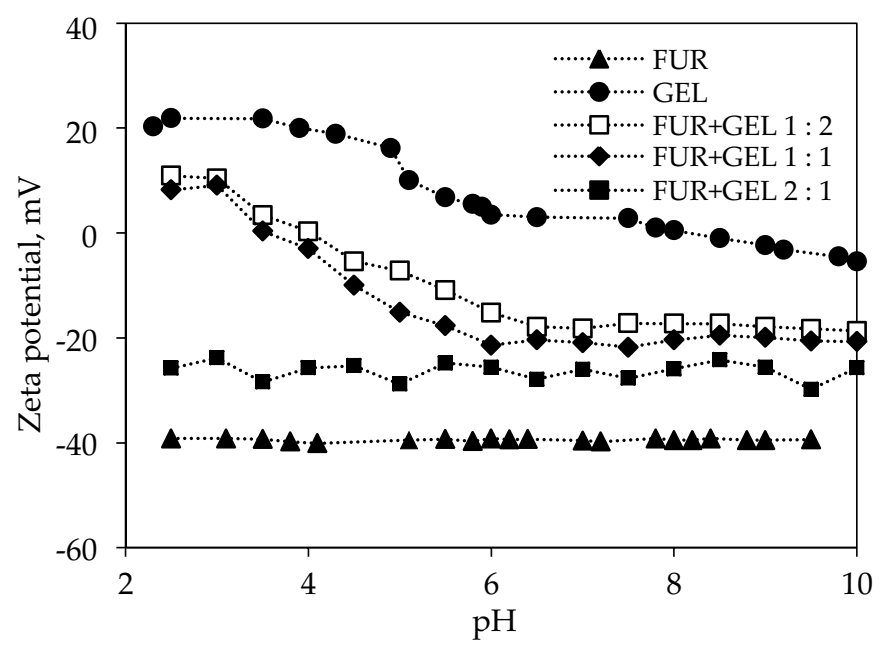

Fig. 1. The zeta potential measurement of individual FUR, GEL and FUR+GEL mixtures in different ratios as a function of $\mathrm{pH}$, measurements in $0.005 \mathrm{M} \mathrm{NaCl}$; FUR - furcellaran, GEL - gelatin, FUR+GEL $1: 2$ - furcellaran + gelatin mixture in ratio $1: 2$, FUR+GEL $1: 1$ - furcellaran + gelatin mixture in ratio $1: 1$, FUR+GEL $2: 1$ - furcellaran + gelatin mixture in ratio $2: 1$ 
that the positively charged GEL did not neutralize all of the negative FUR groups. A similar result was observed in the FUR+BSA mixture of the 2 : 1 ratio [23]. At $\mathrm{pH}$ below the isoelectric point of the proteins, the net positive charge of proteins interacted with the anionic groups of the polysaccharide. For a high protein to FUR ratio, the zeta potential of such mixtures was slightly lower than that for individual proteins. The measured net charge of all mixture FUR+GEL = 1:2 were positive and similar to those for protein, indicating an excess of protein.

\section{Electrochemical synthesis and characterization of FUR/protein complexes}

The FUR/protein complexes were prepared through electrosynthesis. The complexes collected from the anode were colorless, gummy materials, which gradually solidified into a hard sponge. The 1 : 1 FUR blends with either GEL or BSA yielded corresponding complexes. The formation of the FUR/BSA complex was slower than the formation of the FUR/GEL complexes. After 60 minutes, the yield of the complexes was 55 and $65 \%$, respectively. In the reaction course, the initial $\mathrm{pH}$ changed over time stabilizing within the first $20 \mathrm{~min}$. On synthesis of the FUR/GEL complex, the initial $\mathrm{pH}$ of 5.60 increased to 10.55 whereas on synthesis of the FUR/BSA complex, the $\mathrm{pH}$ rose from $\mathrm{pH} 6.95$ to 11.30 . This showed that, due to discharge of the cations of the IA and IIA groups present in the reagents, the isoelectric point specific for the formation of water insoluble complexes was reached at the anode. Electrosynthesis automatically adjusted the $\mathrm{pH}$ of the reaction mixtures in a range corresponding to an electrical compatibility of components.

The FUR/GEL and FUR/BSA complexes were prepared by electrosynthesis from aqueous solutions of both components taken in the ratio $1: 1$. This proportion was chosen after the estimation of the zeta potential and yield measurements of complexes. At component ratios differ-

T a b l e 2. Nitrogen and sulfur content in complexes and in their components

\begin{tabular}{c|c|c}
\hline Symbol fo sample & Nitrogen, $\%$ & Sulfur, $\%$ \\
\hline BSA & 14.66 & 1.64 \\
GEL & 16.63 & 0.50 \\
FUR & - & 4.14 \\
FUR/GEL complex & 10.00 & 2.81 \\
FUR/BSA complex & 8.86 & 2.24 \\
\hline
\end{tabular}

T a b l e 3. Characteristic bands of FT-IR spectra of complexes and their components

\begin{tabular}{c|c|c|c|c}
\hline \multicolumn{5}{c}{ Wave number $\left(\mathrm{cm}^{-1}\right)$ and band assignment } \\
\hline FUR & BSA & GEL & FUR/BSA & FUR/GEL \\
\hline $1064 \delta_{\mathrm{C}-\mathrm{O}}$ & - & - & 1069 & 1072 \\
- & $1533 \delta_{\mathrm{C}-\mathrm{N}}$ & $1547 \delta_{\mathrm{C}-\mathrm{N}}$ & 1533 & 1535 \\
- & $1659 \gamma_{\mathrm{C}=\mathrm{O}}$ & $1662 \gamma_{\mathrm{C}=\mathrm{O}}$ & 1663 & 1659 \\
\hline
\end{tabular}

ent from $1: 1$, an increase in the protein or polysaccharide content in the solution was paralleled by an increase in the protein or polysaccharide content in the complex. The results of the elemental N, S analysis (Table 2) confirmed the stoichiometric $1: 1$ ratio for the FUR/GEL and FUR/BSA complexes.

Based on the nitrogen content in the complexes, it was found that both complexes contained $59 \%$ protein and $41 \%$ FUR, whereas the estimations based on the determination of the sulfur content gave $53 \%$ and $47 \%$, protein and FUR, respectively.

The investigated complexes differed in their solubility. At room temperature, the solubility of FUR/GEL and FUR/BSA complexes was $0.055 \pm 0.021 \mathrm{~g} / 100 \mathrm{~cm}^{3} \mathrm{H}_{2} \mathrm{O}$ and $0.031 \pm 0.020 \mathrm{~g} / 100 \mathrm{~cm}^{3} \mathrm{H}_{2} \mathrm{O}$, respectively. Moreover, DMSO (dimethyl sulfoxide) and $7 \mathrm{M}$ aq. urea solution did not dissolve the tested complexes. A low aqueous solubility of complexes is typical for the products of the combination of anionic polysaccharides and proteins [10, 15].

The characteristic bands on the FT-IR spectra of FUR, BSA and GEL, as well as the FUR/BSA and FUR/GEL complexes are presented in Table 3.

The spectral pattern of the FUR/protein complexes might be considered as a superposition of the spectra of both components. The amide I band $\left(\sim 1659 \mathrm{~cm}^{-1}\right.$, stretching carbonyl vibrations) and amide II band $\left(\sim 1535 \mathrm{~cm}^{-1}\right.$, stretching C-N vibrations), characteristic for GEL ( 1662 and $\sim 1547 \mathrm{~cm}^{-1}$, respectively), and the band at $1072 \mathrm{~cm}^{-1}$ ascribed to $\mathrm{C}-\mathrm{O}$ stretching vibrations, characteristic for FUR $\left(1064 \mathrm{~cm}^{-1}\right)$, were present in the spectrum of the complex, but they were shifted with respect to the position of the corresponding bands for the pure components. These shifts indicated that the electrosynthesis led to complex formation, and these spectral changes confirmed the character of protein-polysaccharide interactions.

The thermal properties (DSC) of the physical mixtures of the components and relevant complexes are demonstrated in Fig. 2a and Fig. 2b, for FUR-GEL and FUR-BSA systems, respectively. The diagrams showed that the products collected from the anode could not be the physical mixtures of the components. Some down shifts of the thermal effects could suggest some degradation of the materials under alkaline conditions generated in the course of the complex formation. Formation of the polysaccharide/protein complexes was also confirmed by the thermogravimetric analysis (TG and DTG, Fig. 3a and Fig. 3b).

The TG lines in diagrams of the complexes showed different patterns from the pattern in the diagrams for the physical mixtures of the components. In the thermogram of FUR+GEL mixture and FUR/GEL complexes, very fast decomposition occurred at $183^{\circ} \mathrm{C}$ and $215^{\circ} \mathrm{C}$, respectively. The DTG peaks were very sharp. The FUR+BSA mixture and FUR/BSA complex decomposed with an initial loss of $15 \%$ water as manifested by a peaks with its maximum at $64{ }^{\circ} \mathrm{C}$. Then, the FUR+BSA mixture decomposed gradually in at least three steps with the main decom- 

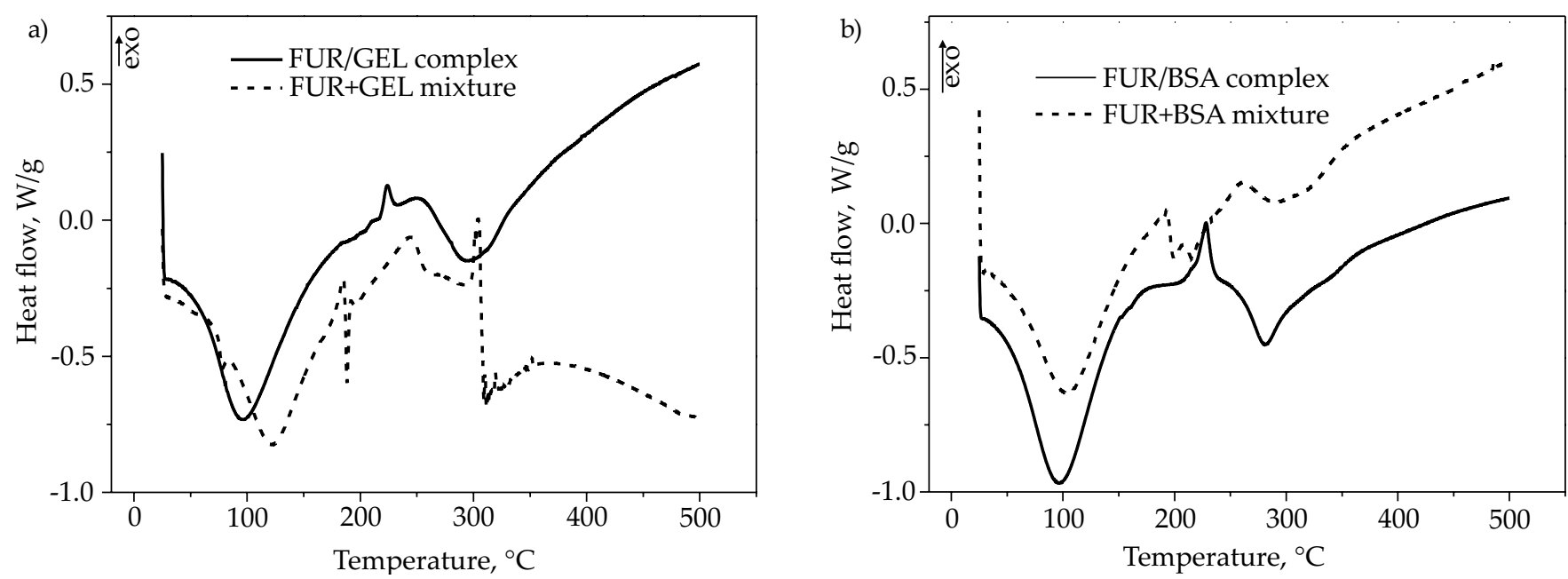

Fig. 2. DSC curves of: a) FUR/GEL complexes and FUR+GEL mixtures, b) FUR/BSA complexes and FUR+BSA mixtures
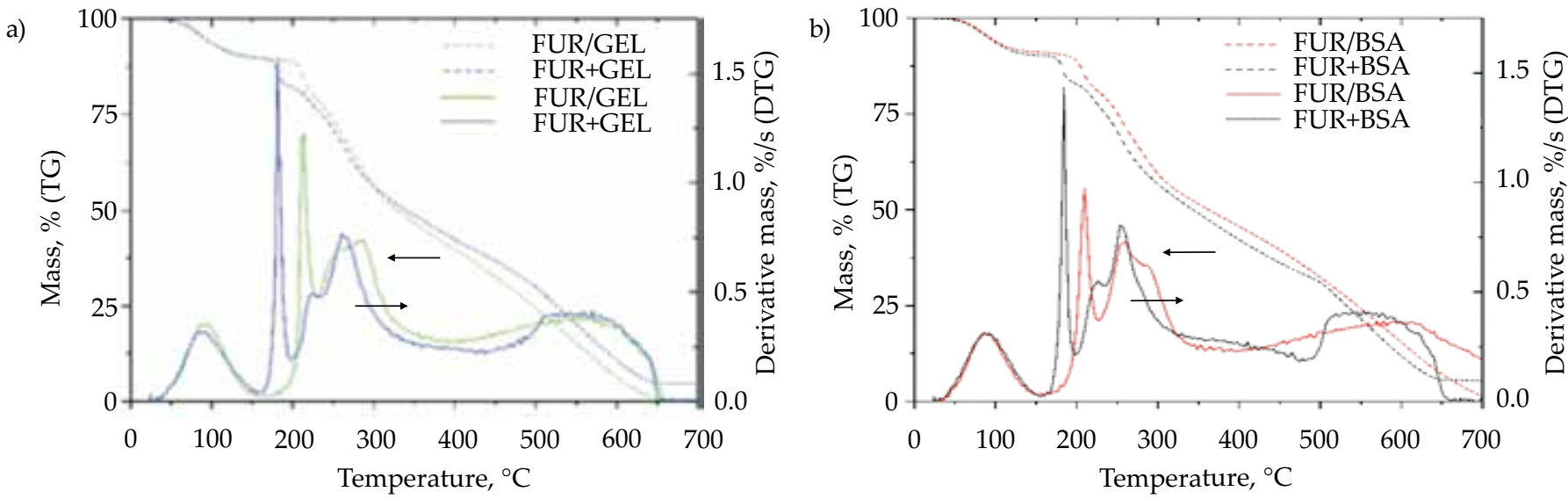

Fig. 3. Thermograms (TG and DTG) of: a) FUR/GEL complexes and FUR+GEL mixtures, b) FUR/BSA complexes and FUR+BSA mixtures

position at $179{ }^{\circ} \mathrm{C}$, and decomposition of the FUR/BSA complex occurred at $220^{\circ} \mathrm{C}$. The TG curves of FUR/BSA and FUR/GEL complexes in the range of $200-650^{\circ} \mathrm{C}$ were very steep.

Using glucoamylase, enzymatic hydrolysis was performed on FUR in physical mixtures of proteins as well as in FUR/GEL and FUR/BSA complexes. This series of

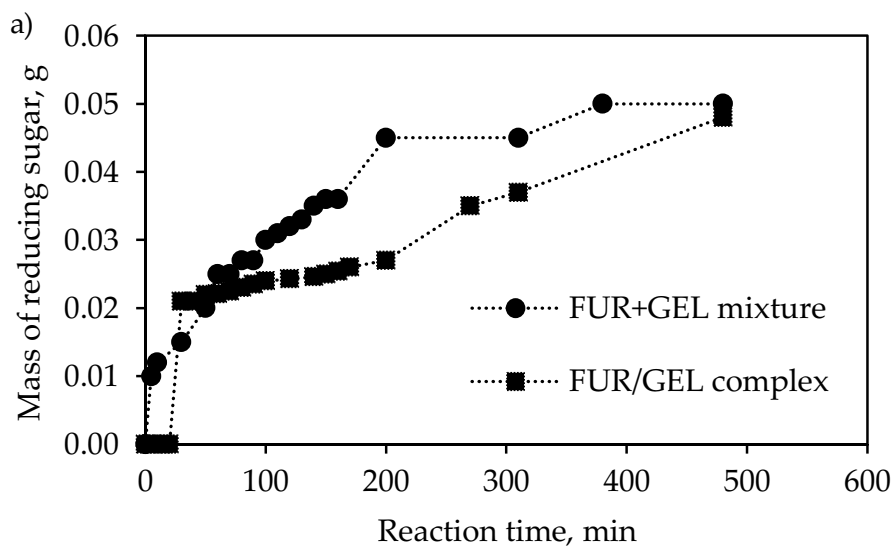

experiments delivered further arguments speaking for the formation of complexes. Figures $4 \mathrm{a}$ and $4 \mathrm{~b}$ demonstrate the course of hydrolysis of $1: 1$ physical mixtures of FUR and its complexes with GEL and BSA, respectively.

FUR in the complexes was digested within three steps, but in physical mixtures it hydrolyzed in four stages. In every step, there was a linearity of the reducing sugar

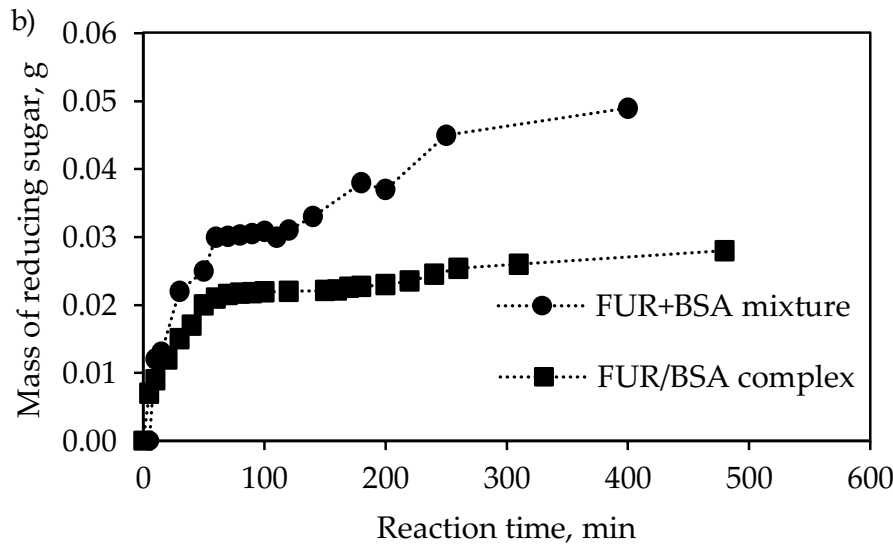

Fig. 4. Time-dependent level of reducing sugar in materials digested with glucoamylase: a) furcellaran and gelatin and their complex, b) furcellaran and albumin and their complex 

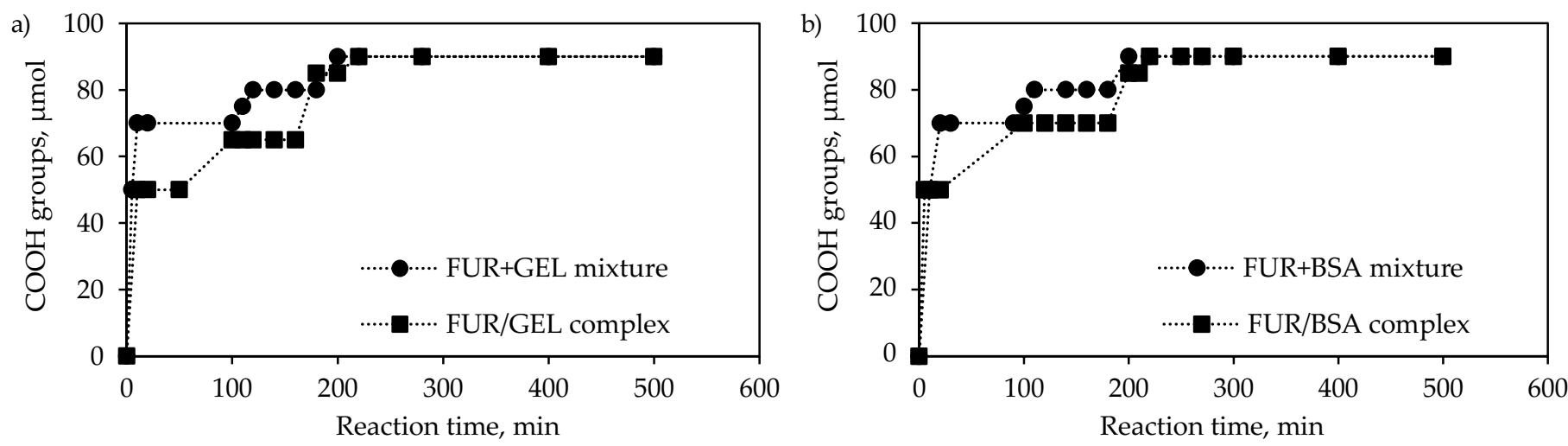

Fig. 5. Time-dependent level of reducing protein in materials digested with trypsin of: a) furcellaran and gelatin and their complex, b) furcellaran and albumin and their complex

$T$ a b 1 e 4. Reaction rate constants of the hydrolysis with glucoamylase of furcellaran in FUR/GEL and FUR/BSA complexes and $1: 1$ physical mixtures and rate constants of the hydrolysis with trypsin of the protein components in FUR/GEL and FUR/BSA complexes and $1: 1$ physical mixtures

\begin{tabular}{|c|c|c|c|c|c|c|}
\hline \multicolumn{6}{|c|}{$\begin{array}{l}\text { Rate constants }(k) \text { of the hydrolysis with glucoamylase of furcellaran in complexes and } 1: 1 \text { physical mixtures } \\
\mathrm{g} / \mathrm{min}\end{array}$} & \multirow{2}{*}{$\begin{array}{c}\text { The reaction time } \\
\text { of total hydrolysis } \\
\text { of FUR, min }\end{array}$} \\
\hline & $k_{1}$ & \multicolumn{2}{|c|}{$k_{2}$} & $k_{3}$ & $k_{4}$ & \\
\hline FUR/BSA & $3.0 \cdot 10^{-4}$ & \multicolumn{2}{|c|}{$6.1 \cdot 10^{-5}$} & $2.9 \cdot 10^{-5}$ & - & - \\
\hline FUR/GEL & $4.8 \cdot 10^{-4}$ & \multicolumn{2}{|c|}{$5.5 \cdot 10^{-5}$} & $6.3 \cdot 10^{-5}$ & - & $>480$ \\
\hline FUR+BSA & $6.7 \cdot 10^{-4}$ & \multicolumn{2}{|c|}{$4.3 \cdot 10^{-5}$} & $14.5 \cdot 10^{-5}$ & $1.3 \cdot 10^{-5}$ & 380 \\
\hline FUR+GEL & $3.9 \cdot 10^{-4}$ & \multicolumn{2}{|c|}{$10.0 \cdot 10^{-5}$} & $32.0 \cdot 10^{-5}$ & $1.3 \cdot 10^{-5}$ & 380 \\
\hline \multicolumn{6}{|c|}{$\begin{array}{l}\text { Rate constants }(k) \text { of the hydrolysis with trypsin of the protein in complexes and } 1: 1 \text { physical mixtures } \\
\qquad \mu \mathrm{mol} / \mathrm{min}\end{array}$} & \multirow{2}{*}{$\begin{array}{c}\text { The reaction time } \\
\text { of total hydrolysis } \\
\text { of protein, min }\end{array}$} \\
\hline & & $k_{1}$ & $k_{2}$ & $k_{3}$ & $k_{4}$ & \\
\hline \multicolumn{2}{|c|}{ FUR/BSA } & 10 & 0.4 & 0.6 & 0.1 & 225 \\
\hline \multicolumn{2}{|c|}{ FUR/GEL } & 10 & 0.2 & 0.3 & 0.1 & 480 \\
\hline \multicolumn{2}{|c|}{ FUR+BSA } & 10 & 1.8 & 0.7 & 0.4 & 180 \\
\hline \multicolumn{2}{|c|}{ FUR+GEL } & 10 & 1.0 & 1.0 & 0.7 & 180 \\
\hline
\end{tabular}

content against time, indicating the zero-order of the reactions induced by the maximum saturation of the substrate with the enzyme. Reaction rate constants for every hydrolysis reaction step are reported in Table 4.

It could be seen that the FUR/GEL complex hydrolyzed with a higher rate possibly for the structure of the complex being more adjustable for the hydrolysis with the polysaccharide enzyme. The lower rate constant for initial $k_{1}$ and final $k_{3}$ stages of the hydrolysis were characteristic for the hydrolysis of the FUR/BSA complex. It could be controlled by a difficult access of the enzyme to the appropriate reaction sites of the complex. The hydrolysis of FUR in the FUR+GEL and FUR+BSA mixtures was completed within about 380 minutes. In turn, the total hydrolysis of FUR in the FUR/GEL and FUR/BSA complexes proceeded with a lower rate.

Trypsin was applied for the hydrolysis of protein components of the complexes and their physical mixtures with FUR. Progress in the protein hydrolyses with trypsin was accompanied with an increase in the content of the carboxylic groups determinable with the formol Sörensen method [25]. The carboxylic groups neutralized by ammonia could not be directly titrated with alkali. In order to liberate the blocked carboxylic groups, ammonium cations were reacted with formaldehyde to give a methylene derivative of the peptide. The course of the titration of FUR/GEL and FUR/BSA complexes and corresponding $1: 1$ physical mixtures of the components are presented in Figs. 5a and 5b, respectively.

The relevant hydrolysis rate constants for each stage of the hydrolysis are collected in Table 4. These diagrams and determined rate constants indicated that the hydrolysis of GEL in both samples proceeded in four stages. Initially the hydrolysis was fast then, already in the second stage, it significantly slowed down. BSA hydrolyzed in four stages and the initial stage was very fast.

The complete hydrolysis of GEL in the complex took about 480 min whereas in the mixture it lasted only about 180 min. BSA fully hydrolyzed within 225 and $180 \mathrm{~min}$ when it resided in the complex and the physical mixture, respectively.

The morphology of the dry complexes was examined by scanning electron microscopy (SEM). The examples of SEM images are presented in Figs. $6 a$ and $6 b$. 
a)

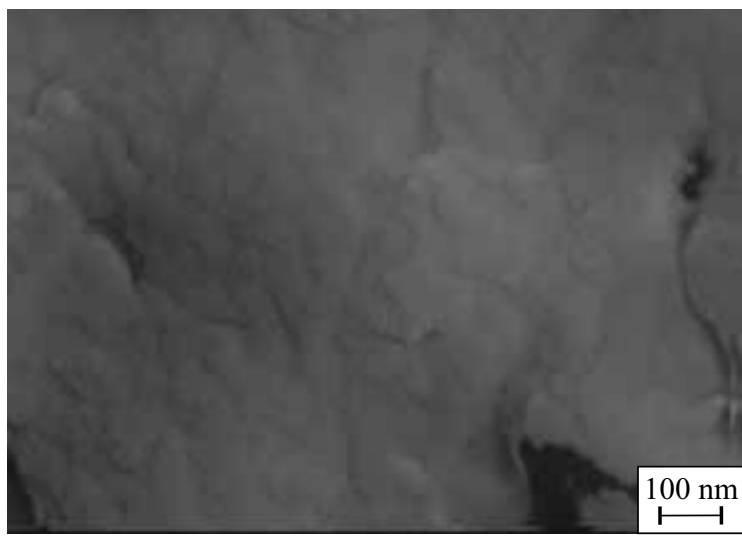

b)

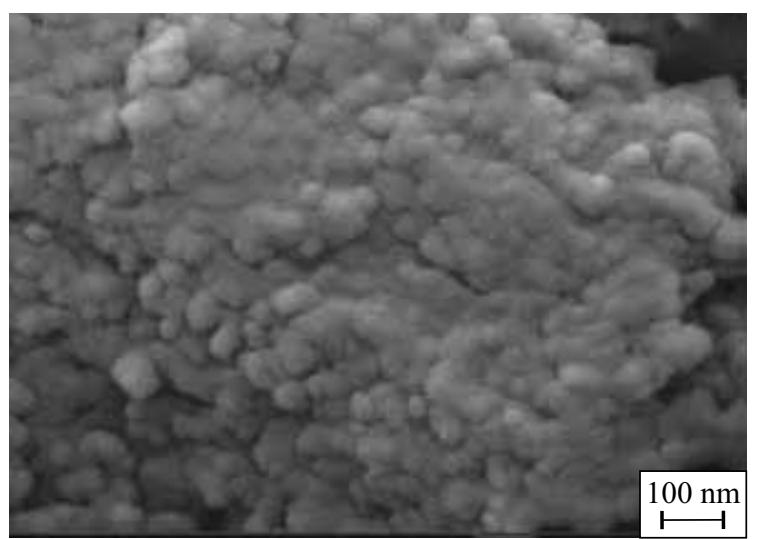

Fig. 6. Scanning electron microphotographs of: a) the FUR/GEL complex, b) the FUR/BSA complex

The surface structure of the FUR/GEL complex was homogeneous, in contrast to the granular structure of the surface of the FUR/BSA complex. Differences in their structure could relate to the differences in solubility and hydrolytic susceptibility of both complexes. The FUR/GEL complex appeared to be a suitable component of biodegradable foils [14] and the FUR/BSA complex can be utilized as a core of nanocapsules [36].

\section{CONCLUSIONS}

The electrosynthesis appeared suitable for the formation of binary complexes of furcellaran with proteins such as gelatin and bovine serum albumin.

The formation of the complexes can be controlled by the individual components and by the reaction conditions. The results of the electrosynthesis presented in this paper showed that the polysaccharide/protein ratio and $\mathrm{pH}$ are influential factors in the zeta potential.

High yields of the formation of complexes were promising for the development of a high scale production. Enzymatic studies showed that the furcellaran/gelatin and furcellaran/bovine serum albumin complexes are biodegradable.

\section{REFERENCES}

[1] Tomasik P., Schilling C.: Advances in Carbohydrate Chemistry and Biochemistry 1998, 53, 345. http://dx.doi.org/10.1016/s0065-2318(08)60046-3

[2] Turgeon S.L., Schmitt C., Sanchez C.: Current Opinion in Colloid and Interface Science 2007, 12, 166. http://dx.doi.org/10.1016/j.cocis.2007.07.007

[3] Zaleska H., Tomasik P., Ring S.: Carbohydrate Polymers 2001, 45, 89. http://dx.doi.org/10.1016/S0144-8617(00)00239-3

[4] Zaleska H., Ring S., Tomasik P.: International Journal of Food Science \& Technology 2001, 36, 509. http://dx.doi.org/10.1046/j.1365-2621.2001.00491.x

[5] Grega T., Najgebauer D., Sady M. et al.: Journal of Polymers and the Environment 2003, 11, 75. http://dx.doi.org/10.1023/A:1024275906612
[6] Najgebauer D., Grega T., Sady M. et al.: Journal of Polymers and the Environment 2004, 12, 17. http://dx.doi.org/10.1023/B:JOOE.0000003124.39173.8f

[7] Najgebauer D., Grega T., Sady M. et al.: Molecules 2004, 9, 550.

http://dx.doi.org/10.3390/90700550

[8] Lii C.Y., Tomasik P., Zaleska H. et al.: Carbohydrate Polymers 2002, 50, 19. http://dx.doi.org/10.1016/S0144-8617(01)00372-1

[9] Zaleska H., Tomasik P., Lii C.Y.: Food Hydrocolloids 2002, 16, 215.

http://dx.doi.org/10.1016/s0268-005x(01)00085-6

[10] Zaleska H., Tomasik P., Lii C.Y.: Journal of Food Engineering 2002, 53, 249.

http://dx.doi.org/10.1016/s0260-8774(01)00163-7

[11] Lii C.Y., Chan H.H., Tomasik P. et al.: Journal of Polymers and the Environment 2003, 11, 115. http://dx.doi.org/10.1023/A:1024687115062

[12] Lii C.Y., Chen H.H., Lu S. et al.: International Journal of Food Science \& Technology 2003, 38, 787. http://dx.doi.org/10.1046/j.1365-2621.2003.00733.x

[13] Burova T.V., Grinberg N.V., Grinberg V.Y. et al.: Biomacromolecules 2007, 8, 368. http://dx.doi.org/10.1134/S0965545X0904004X

[14] Jamróz E., Konieczna-Molenda A., Para A.: Polimery 2017, 62, 673.

http://dx.doi.org/10.14314/polimery.2017.673

[15] Dejewska A., Mazurkiewicz J., Tomasik P. et al.: Starch/Stearke 1995, 47, 219. http://dx.doi.org/10.1002/star.19950470606

[16] Zaleska H., Mazurkiewicz J., Tomasik P. et al.: Nahrung 1999, 43, 278. http://dx.doi.org/10.1002/(SICI)1521-3803

[17] Zaleska H., Ring S., Tomasik P.: Food Hydrocolloids 2000, 14, 377. http://dx.doi.org/10.1016/S0268-005X(00)00014-X

[18] Li J.L., Cheng Y.Q., Wang P. et al.: Food Hydrocolloids 2012, 26, 448. http://dx.doi.org/10.1016/j.foodhyd.2010.11.015

[19] Khachatryan G., Khachatryan K., Grzyb J. et al.: Carbohydrate Polymers 2016, 151, 452.

https://doi.org/10.1016/j.carbpol.2016.05.104 
[20] Białopiotrowicz T., Jańczuk B., Fiedorowicz M. et al.: Materials Chemistry and Physics 2006, 95, 99. http://dx.doi.org/10.1016/j.matchemphys.2005.06.003

[21] Lii C.Y., Liaw S.C., Lai V.M. et al.: European Journal of Polymers 2002, 38, 1377. http://dx.doi.org/10.1016/S0014-3057(02)00008-3

[22] Lii C.Y., Liaw S.C., Tomasik P.: Polish Journal of Food and Nutrition Sciences 2003, 12 (3), 25.

[23] Huang G.Q., Sun Y.T., Xiao J.X. et al.: Food Chemistry 2012, 135, 534. http://dx.doi.org/10.1016/j.foodchem.2012.04.140

[24] Lin M., Meng S., Zhong W. et al:: Journal of Pharmaceutical Sciences 2008, 97, 4240. http://dx.doi.org/10.1002/jps.21297

[25] Schilling C.H., Karpovich D., Tomasik P.: Journal of Biobased Materials and Bioenergy 2009, 3, 1. http://dx.doi.org/10.1166/jbmb.2009.1044

[26] Schilling C.H., Tomasik P., Karpovich D.S. et al.: Journal of Polymers and the Environment 2004, 12, 257. http://dx.doi.org/10.1007/s10924-004-8317-z

[27] Schilling C.H., Tomasik P., Karpovich D.S. et al.: Journal of Polymers and the Environment 2005, 13, 57. http://dx.doi.org/10.1007/s10924-004-1216-5

[28] Schilling C.H., Tomasik P., Karpovich D.S. et al.: Journal of Polymers and the Environment 2005, 13, 177. http://dx.doi.org/10.1007/s10924-005-2948-6

[29] Schilling C.H., Tomasik P., Karpovich D.S. et al.: Journal of Polymers and the Environment 2005, 13, 203. http://dx.doi.org/10.1007/s10924-005-4755-5

[30] Devi N., Sarmah M., Khatun M. et al.: Advances in Colloid and Interface Science 2017, 239, 136.

http://dx.doi.org/10.1021/la0262405

[31] Laos K., Brownsey G.J., Ring S.G.: Carbohydrate Polymers 2007, 67, 116. http://dx.doi.org/10.1016/j.carbpol.2006.04.021

[32] Yin S.Y., Tang C.H., Cao J.S. et al.: Food Chemistry 2008, 106, 1004.

http://dx.doi.org/10.1016/j.foodchem.2007.07.030

[33] Guan X., Yao H.Y., Chen Z.X. et al.: Food Chemistry 2007, 101, 163.

http://dx.doi.org/10.1016/j.foodchem.2006.01.011

[34] Chen M., Zhao J., Xia L.: Carbohydrate Polymers 2008, $71,411$.

http://dx.doi.org/10.1016/j.carbpol.2007.06.011

[35] Mkeder I., Travelet Ch., Durand-Terrasson A. et al.: Carbohydrate Polymers 2013, 94, 934.

http://dx.doi.org/10.1016/j.carbpol.2013.02.001

[36] Jamróz E., Para G., Jachimska B. et al.: Colloids and Surface A: Physicochemical and Engineering Aspects 2014, 441, 880.

http://dx.doi.org/10.1016/j.colsurfa.2013.01.002

[37] Miller G.L.: Analytical Chemistry 1959, 31, 426.

[38] Kaczkowski J.: "Fundamentals of Biochemistry" (in Polish) WNT, Warsaw 2005.

Received 17 X 2017

\section{INSTYTUT INŻYNIERII MATERIAŁÓW POLIMEROWYCH I BARWNIKÓW w TORUNIU ODDZIAŁ FARB i TWORZYW w GLIWICACH zaprasza do udziału w XIII Międzynarodowej Konferencji}

\section{ADVANCES IN COATINGS TECHNOLOGY (POSTĘPY W TECHNOLOGII FARB I LAKIERÓW)}

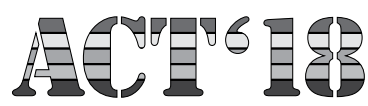

która odbędzie się w Sosnowcu, w dniach 13-15 listopada 2018 r.

Tematyka Konferencji:

- Nowości w zakresie bazy surowcowej dla wyrobów lakierowych:

- Nowoczesne, przyjazne środowisku technologie wytwarzania wyrobów lakierowych:

- Analiza i badania wyrobów lakierowych oraz powłok

- Aparatura do produkcji wyrobów lakierowych

- Zagadnienia ekologiczne (uwarunkowania legislacyjne)

- Kierunki rozwojowe rynku

Językiem konferencji będzie język angielski/polski, z symultanicznym tłumaczeniem.

Czas prezentacji referatu - 20 minut.

Tytuł referatu (plakatu) wraz z jego skrótem oraz biografią osoby prezentującej powinny być dostarczone do 31 maja 2018 r., pełne teksty referat do 31 sierpnia 2018 r.

Opłata konferencyjna dla osoby wygłaszającej referat lub prezentującej plakat wynosi 1000 zł + $23 \%$ VAT. Miejsce konferencji: Centrum EXPO SILESIA, Sosnowiec, ul. Braci Mieroszewskich 124.

Informacje: mgr inż. Anna Pająk - Komitet Organizacyjny Konferencji ACT'16, tel. +48 (32) 231 9043, fax: +48 (32) 231 2674, e-mail: a.pajak@impib.pl, Instytut Inżynierii Materiałów Polimerowych i Barwników,

Oddział Zamiejscowy Farb i Tworzyw, ul. Chorzowska 50A, 44-100 Gliwice

www.impib.pl 